\title{
Does Social Parameters and Landholding Size Affect Household Food Security in Rural India?
}

\author{
D. J. Nithya*, S. Raju, Akshaya Kumar Panda \\ M. S. Swaminathan Research Foundation, Taramani, Chennai, India \\ Email: ^djnithya@mssrf.res.in, rajumssrf@gmail.com, akshay@mssrf.res.in
}

How to cite this paper: Nithya, D. J., Raju, S., \& Panda, A. K. (2021). Does Social Parameters and Landholding Size Affect Household Food Security in Rural India? Open Journal of Social Sciences, 9, 201-212. https://doi.org/10.4236/jss.2021.911017

Received: September 13, 2021

Accepted: November 23, 2021

Published: November 26, 2021

Copyright $\odot 2021$ by author(s) and Scientific Research Publishing Inc. This work is licensed under the Creative Commons Attribution International License (CC BY 4.0).

http://creativecommons.org/licenses/by/4.0/

(c) (i) Open Access

\begin{abstract}
Past studies have proved that various factors affect household food security. This paper presents whether social groups, family size and landholding sizes are related to food security of the households. Consumption of food groups as per household recommended requirement is considered as food security in this paper. Subsample of 315 households from 39 villages of Mathapada Gram Panchayat and 8 villages from Doraguda Gram Panchayat in Boipariguda block in Koraput district of Odisha state, India were taken for the study. Results of the study show that social group and family size have significant effect on the gap between consumption and household food groups and nutrients requirement, while landholding did not show any effect. Intervention studies and knowledge on consumption of own production and marketing of excess produce should be emphasized. Government entitlements should focus on decreasing the gap between the consumption and household requirement by increasing the accessibility to foods and making the rural households food secure.
\end{abstract}

\section{Keywords}

Family Size, Social Group, Landholding Size, Food Security

\section{Introduction}

Food security is defined as "a situation that exists when all people, at all times, have physical, social and economic access to sufficient, safe and nutritious food that meets their dietary needs and food preferences for an active and healthy life" (FAO, 2003). This definition consists of four central parts: availability, stability, accessibility and utilization. A food system is said to be vulnerable when one or more of the four components of food security are uncertain and insecure (FAO, 2008). Household food security is the application of this concept to the 
family level, with individuals within households as the focus of concern (FAO, 2003).

There are many factors that affect the household food security and past researches have used family size, gender and age of household head; size of the land holding, nature of the ownership of the assets, off farm/non-farm income sources, consumption pattern, food and input prices; and access to markets, availability of marketing infrastructures and roads, extension services, etc. Abdullah et al. (2019) conducted a binary logistics regression technique to determine the factors that influence household food insecurity and reported that age, gender, education, remittances, unemployment, inflation, assets, and disease are important factors and gender played a dominant role. Nkomoki et al. (2019) conducted two ordered probit models with food consumption score (FCS) and the household hunger scale (HHS) and revealed that higher education levels of household head, increasing livestock income, secure land tenure, increasing land size, and group membership increase the probability of household food and nutrition security. Another study conducted in Nepal by Joshi \& Joshi (2016) showed that size of the land holding, nearness to the market, male headed household, households members with agriculture and allied occupation and the educational level of household head were positive and significant variables while household size was negative and significant variable to food security. Multivariate binary logistic regression model conducted by Sarkar \& Shekhar (2017) showed that education of head of the household, social groups, source of income, Monthly per Capita Expenditure (MPCE) status and availability of livestock were significantly associated with the household food security. Ahmed et al. (2017) conducted logistic regression and showed that family size, monthly income, food prices, health expenses and debt are main factors influencing the food security status of rural households. Sani \& Kemaw (2019) revealed that age of the household head, family size, off-farm and non-farm income positively affected extent of households food insecurity; whereas access to irrigation, farm income, distance to market and access to credit negatively affected the extent of households' food insecurity. Regression analysis results of another study (Sekhampu, 2013) showed that total household income, household size, employment and marital status of the household head, employment status of the spouse as important determinants of food security. A study by (De Cock et al., 2013) investigated the determinants of food security in rural South Africa, and the multivariate regression analyses showed that household size was a major determinant of household food security, and a smaller household size was less likely to be food-insecure.

Social factors such as castes and sub castes play an important role in rural areas as incidence of malnutrition is high among scheduled castes and scheduled tribes and are considered in limited number of studies. In the present paper, food consumption was used as an indicator of food security and the three factors, viz, social, family size and landholding size were used in the present paper to study whether these factors actually affect the household food security in rural 
villages of Koraput district, Odisha.

This study was conducted as a part of the project "Strengthening Livelihoods and Enhancing Food and Nutrition Security of Small and Marginal Farmers in Koraput District of Odisha through a Farming System Model” funded by Department of Agriculture and Farmer's Empowerment, Govt. of Odisha under Rashtriya Krishi Vikas Yojana (RKVY). The project intervention includes promotion of nutrient dense foods like millets, pulses, fruits and vegetables, poultry and fishery to improve the livelihood and health of small and marginal farmers.

\section{Methodology}

\subsection{Study Location}

Thirty nine villages of Mathapada Gram Panchayat and eight villages from Doraguda Gram Panchayat in Boipariguda block were taken for the study. A house listing survey was undertaken to understand the socio-demographic profile of the study villages. Totally, there are 1575 households in the selected 47 villages with a population of 6795 (3360 males and 3435 females). Majority are scheduled tribes (74\%) and lived in semi pucca house (54\%). About 53\% of the head of the households are farmers; $22 \%$ are agriculture labours and $20 \%$ are engaged in non-agriculture wage labour. The total operational land is 1528 hectares and since Koraput is a hilly region, different land pattern is observed: $54 \%$ of the total lands are under upland, 30\% under lowland and 16\% under medium land. About $42 \%$ of the households have marginal land ( $<1 \mathrm{ha}$ ) followed by small land (1 to 2 ha) (24\%); semi medium land ( 2 to 4 ha) (11\%); medium land (4 to 10 ha) $(3 \%) ; 21 \%$ of the households are landless.

\subsection{Sampling}

Subsample of 315 households (20\% of total households) was selected by random sampling method using SPSS statistical software (version 20). A survey was conducted using structured questionnaires for the subsample households during March-April 2019, in order to understand the agriculture pattern, home garden, fishery, livestock and household food consumption pattern and nutrition knowledge. It was ensured that the distribution of socio-economic variables and land class remained similar between the subsample households and total population.

\subsection{Survey}

\subsubsection{Agriculture, Home Garden, Fishery and Poultry}

Details on crops cultivated in upland, medium land and lowland in Kharif season for the period of June to November 2018 and rabi season for the period of December 2017 to May 2018, total operational land, crops grown, home garden details on vegetables and fruits grown last year were collected. Apart from these existing status of pisiciculture and backyard poultry were also collected.

\subsubsection{Food Consumption}

Quantity of food items consumed by household during the month of February 
2019 and their sources were collected using a structured schedule. The information was collected from the women of the household or from the person responsible for cooking. Food groups categorised and nutrients were calculated based on the Indian Food Composition Tables published by the Indian Council for Medical Research (ICMR, 2017). The gap in the food group intake and nutrient intake was calculated by finding the difference between the amount of foods or nutrient required for the family based on the RDI and RDA (recommended dietary intake and recommended dietary allowance) and actual consumption.

\subsection{Statistical Analysis}

ANOVA and linear regression was used to assess the effect of social parameters, family size and land size on the food consumption. STATA and SPSS are the statistical packages that were used for the analysis.

\section{Results and Discussion}

Majority of the population in the sample households were schedules tribes (74\%) followed by schedules caste (13\%), other backward classes (12\%) and only $1 \%$ belonging to general category. The house types were semi pucca houses (56\%) and kutcha houses (33\%). Family size in $60 \%$ of the households was 4 to 6 members, 1 to 3 members in $31 \%$ of households and more than or equal 7 members in $9 \%$ of households. Drinking water was sourced from tube well or bore well by $85 \%$ of the households; only $10 \%$ and $4 \%$ of the household sourced tap water and open well or dug well, respectively and $1 \%$ household sourced drinking water from surface water. Toilet facility was available in $70 \%$ of the household but not used due to unavailability of water. Eighty percent of the households had home garden in their backyard area; $81 \%$ of the households had poultry and a few households ( $8 \%$ ) had pond. Most of the households (48\%) had less than 1 hectare of land, $31 \%$ of households had 1 to 2 hectares of land and $11 \%$ of the households were landless. Table 1 shows the socio-demographic profile of the sample households.

Based on the altitude, the study location has 3 types of the land, low land, medium land and upland. During Kharif season (reported for June to November 2018) paddy was cultivated majorly in low land and medium land. Few households cultivate finger millet and little millet in medium land. Millets were cultivated in upland and few households also cultivated short duration paddy and horse gram in upland. During rabi season (December 2017 to May 2018) season, few households cultivated paddy in low land wherever irrigation facility is available.

Different types of vegetables were cultivated in the home garden for an average of 5 months in 2018. About $30 \%$ of households cultivated average 4 vegetables in home garden; 3 vegetables by $22 \%$ of households; 2 vegetables by $14 \%$ of households; 5 vegetables by $12 \%$ of households; 1 vegetable by $8 \%$ of households and 6 vegetables by $7 \%$ of households. Broad beans, maize, pumpkin, cow pea, 
Table 1. Socio economic characteristics of the study population.

\begin{tabular}{|c|c|c|c|c|c|}
\hline Characteristics & $\begin{array}{c}\text { No. of } \\
\text { households }\end{array}$ & $\begin{array}{c}\text { Percentage of } \\
\text { households }\end{array}$ & Characteristics & $\begin{array}{c}\text { No. of } \\
\text { households }\end{array}$ & $\begin{array}{c}\text { Percentage of } \\
\text { households }\end{array}$ \\
\hline Total households & 315 & & \multicolumn{3}{|c|}{ Occupation of head of household } \\
\hline \multicolumn{3}{|c|}{ Social groups } & Farmer & 151 & 47.9 \\
\hline SC & 40 & 12.7 & Agriculture Worker & 62 & 19.7 \\
\hline ST & 233 & 74.0 & Non Agriculture labour & 67 & 21.3 \\
\hline OBC & 37 & 11.8 & Business & 18 & 5.7 \\
\hline General & 5 & 1.6 & Salaried worker & 5 & 1.6 \\
\hline \multicolumn{3}{|c|}{ Family Size } & Pension & 5 & 1.6 \\
\hline 1 to 3 & 98 & 31.1 & Not in labour force & 7 & 2.2 \\
\hline 4 to 6 & 188 & 59.7 & \multicolumn{3}{|c|}{ Toilet facility } \\
\hline$\geq 7$ & 29 & 9.2 & Yes & 222 & 70.5 \\
\hline \multicolumn{3}{|c|}{ House Type } & No & 93 & 29.5 \\
\hline Kutcha & 103 & 32.7 & \multicolumn{3}{|c|}{ Household having home garden } \\
\hline Semi pucca & 177 & 56.2 & Yes & 251 & 79.7 \\
\hline Pucca & 35 & 11.1 & No & 64 & 20.3 \\
\hline \multicolumn{3}{|c|}{ Source of drinking water } & \multicolumn{3}{|c|}{ Household having pond } \\
\hline Open well/dug well & 13 & 4.1 & Yes & 26 & 8.2 \\
\hline Surface water & 4 & 1.3 & No & 289 & 91.7 \\
\hline Tap water supply & 31 & 9.8 & \multicolumn{3}{|c|}{ Household having poultry } \\
\hline Tube well/bore well & 267 & 84.8 & Yes & 254 & 80.6 \\
\hline \multicolumn{3}{|c|}{ Education of head of household } & No & 61 & 19.4 \\
\hline Illiterate & 234 & 74.3 & \multicolumn{3}{|c|}{ Land class } \\
\hline Primary (up to class 5) & 39 & 12.4 & Landless & 34 & 10.8 \\
\hline Middle school (6 - 8 class) & 18 & 5.7 & Marginal (below 1.00 ha) & 152 & 48.2 \\
\hline Secondary ( 9 and 10 class) & 20 & 6.3 & Small (1.00 - $2.00 \mathrm{ha})$ & 97 & 30.8 \\
\hline \multirow[t]{2}{*}{ Graduate and above } & 4 & 1.3 & Semi-medium (2.00 - $4.00 \mathrm{ha})$ & 24 & 7.6 \\
\hline & & & Medium (4.00 - $10.00 \mathrm{ha})$ & 8 & 2.5 \\
\hline
\end{tabular}

brinjal, tomato, beans, papaya, bitter gourd, ladies finger, ridge gourd, drumstick, tapioca, turmeric, French beans, amaranthus, sweet potato, cluster beans, spine gourd, cabbage, cucumber, snake gourd, cauliflower, yam, ivy gourd, bottle gourd, field beans, colocasia, onion, radish and green chillies and fruits like guava, mango and banana were grown in home garden.

All the households consumed cereals and millets, vegetables and fats and oil daily. Rice and finger millet are the major cereals and millets consumed. The quantity of rice consumed was more than the recommended level (462 g against $375 \mathrm{~g}$ RDI). Consumption of other vegetables was good and met the RDI as they were available from home garden. All the other food groups were consumed 
lesser than the recommended level. Although sugars were not consumed by all households, consumption was equal to the recommended level. Table 2 shows the consumption of foods according to food groups (g/CU/day).

The household requirement of cereals and millets, pulses, other vegetables, roots and tubers and fruits was met as per the recommended allowances in the general category which is considered as the most advantaged group in a community. Food requirement of OBC category households, which was second in order of social groups met the household requirement of cereals and millets and roots and tubers while all other food groups did not meet the household requirement. Figure 1 shows the gap in average consumption of different food groups/household/day compared with the household requirement based on recommended dietary intake based on social groups.

Except cereals and millets, all the foods groups were consumed lesser than the household requirement in socially disadvantaged groups viz., Scheduled Castes (SCs), the Scheduled Tribes (STs) households. Wide gap in the consumption and household requirement of milk and milk products was observed in SC (consumption: $51 \mathrm{~g} /$ day) and ST households (consumption: $30 \mathrm{~g} /$ day) when compared to other social groups. The gap between the requirement and consumption of pulses, roots and tubers, fruits and milk and milk products varied significantly based on social groups. Ali et al. (2012) reported that most of food insecure households in Uttar Pradesh, India belong to scheduled caste and backward caste.

Family size played a significant role in the household requirement and consumption of all food groups, except in the requirement of milk and milk products

Table 2. Average consumption of food groups (g/CU/day).

\begin{tabular}{cccc}
\hline Food groups & N & Mean \pm SD & RDI $^{*}$ \\
\hline Cereals and Millets & 315 & $462.32 \pm 158.50$ & 375 \\
Pulses and legumes & 312 & $44.66 \pm 34.53$ & 75 \\
Other vegetables & 315 & $202.74 \pm 126.32$ & 200 \\
Leafy vegetables & 315 & $84.43 \pm 58.68$ & 100 \\
Roots and tubers & 315 & $111.65 \pm 63.90$ & 200 \\
Fruits & 307 & $46.59 \pm 45.36$ & 100 \\
Milk and milk products & 123 & $26.56 \pm 36.28$ & 300 \\
Meat and poultry & 274 & $24.69 \pm 24.75$ & \\
Fishes and sea foods & 250 & $17.42 \pm 17.73$ & \\
Nuts and oil seeds & 266 & $7.63 \pm 9.26$ & \\
Fats and oils & 314 & $16.47 \pm 11.12$ & 25 \\
Sugars & 272 & $20.95 \pm 19.18$ & 20 \\
\hline
\end{tabular}

${ }^{*}$ Recommended Dietary Intake (National Institute of Nutrition, 2011) CU: Consumption Unit: One consumption unit is defined as the calorie consumption of an average adult man, weighing $60 \mathrm{~kg}$, doing sedentary type of work. 


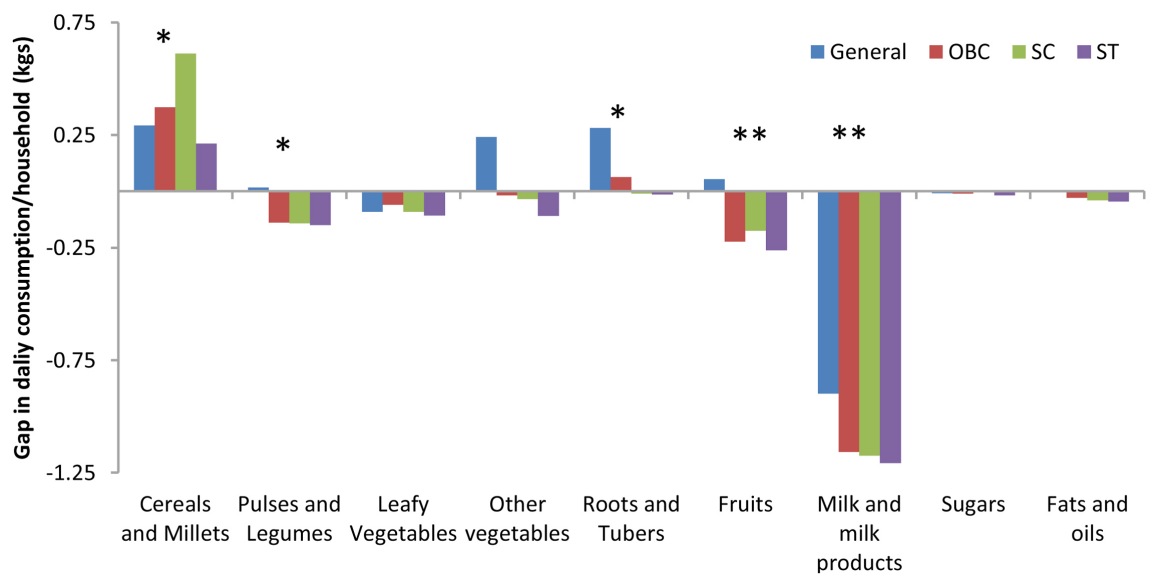

Figure 1. Gap in average consumption of different food groups/household/day compared with the household requirement based on recommended dietary intake according to social groups ${ }^{\star} p<0.05 ;{ }^{* *} p<0.01$.

which was consumed less irrespective of the family size. In a small family size of 1 to 3 member household, the consumption of cereals and millets, pulses, vegetables and sugars met RDI while in large family sizes except cereals all the other food groups were below the required quantity. Pulses and legumes were consumed on an average of $174 \mathrm{~g} /$ day against the household requirement of 345 g/day in 4 to 6 members and $198 \mathrm{~g} /$ day against the household requirement of $518 \mathrm{~g} /$ day in 7 members and above. Other vegetables were consumed on an average of $775 \mathrm{~g} /$ day against the household requirement of $914 \mathrm{~g} /$ day in 4 to 6 members and $879 \mathrm{~g} /$ day against the household requirement of $1382 \mathrm{~g} /$ day in 7 members and above.

Similar results were reported by Sekhampu (2013) and Olayemi (2012) that household size was negatively associated with household food security. Shone et al. (2017) also reported that odds of households with larger family size to be food insecure was higher than households with smaller family sizes. Except for milk and milk products, family size has significant effect on household food requirement. Figure 2 shows the gap in average consumption of different food groups/ household/day compared with the household requirement based on recommended dietary intake based on family size.

Landholding size had significant effect on the consumption of cereals and millets as per requirement. It was observed that all households consumed roots and tubers as per requirement irrespective of the land holding size. The consumption of other vegetables by landless household were found to be as per requirement. All other food groups were consumed less than the requirement in all different land holding sizes.

Nkomoki et al. (2019) reported that the size of land was found to have a positive relationship with food security. Owning smaller farm land increases the risk of being food insecure nearly by 2 times compared to larger land size (Shone et al., 2017). Another study by Agidew \& Singh (2018) reported that the majority of the food insecure households own less than 1 ha of farmlands. Figure 3 shows 


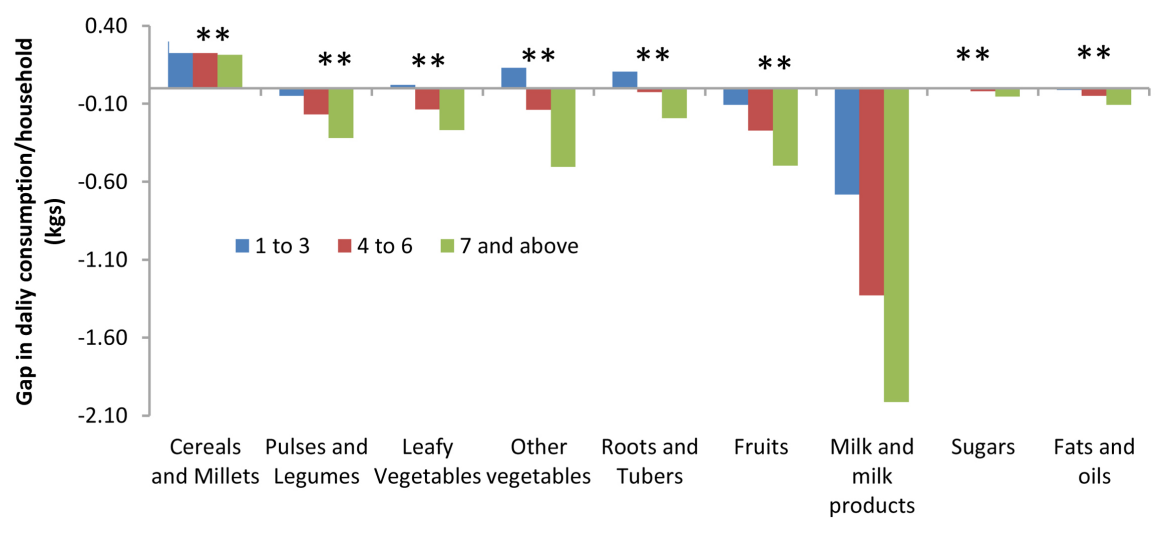

Figure 2. Gap in average consumption of different food groups/household/day compared with the household requirement based on recommended dietary intake according to family size, ${ }^{* *} p<0.01$.

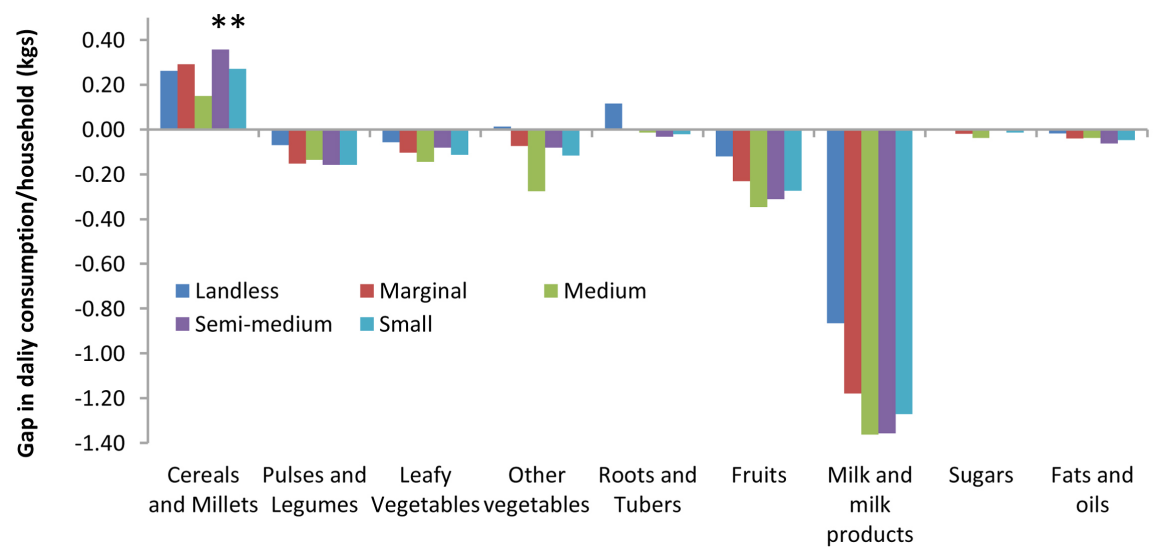

Figure 3. Gap in average consumption of different food groups/household/day compared with the household requirement based on recommended dietary intake according to land class; ${ }^{\star *} p<0.01$.

the gap in average consumption of different food groups/household/day compared with the household requirement based on recommended dietary intake based on landholding size.

Rammohan \& Pritchard (2014) used ordered probit models and indicated that in Myanmar, an increase in land size enhanced household food security status. Muraoka et al. (2018) demonstrated that an increase in land size resulted in a rise in household food security.

Overall, gap between the nutrient requirement and consumption was observed in all nutrients except, vitamin $\mathrm{C}$ and folates. However, the gap between the nutrient requirement and consumption was negative, particularly more in the ST groups, significantly in protein, energy, fats and zinc and also in calcium, vitamin A and iron (Table 3). In contrast to the present result, Behrman \& Deolalikar (1990) reported that household social groups affiliation does not affect the nutrient intake of household members.

The nutrient gap also increases as the family size increases, significantly. Interesting, the gap in the nutrients like protein, energy, calcium, iron and zinc 
Table 3. Nutrient Gap between household requirement and consumption according to social groups.

\begin{tabular}{|c|c|c|c|c|c|c|c|c|c|}
\hline Categories & $\begin{array}{c}\text { Protei } \\
\mathrm{n}, \mathrm{g}\end{array}$ & Fat, $\mathrm{g}$ & $\begin{array}{c}\text { Energy, } \\
\text { kcal }\end{array}$ & $\begin{array}{c}\text { Calcium, } \\
\text { mg }\end{array}$ & $\begin{array}{l}\text { Iron, } \\
\text { mg }\end{array}$ & $\begin{array}{c}\text { Vitamin A, } \\
\mu \mathrm{g}\end{array}$ & $\begin{array}{l}\text { Vitamin } \\
\mathrm{C}, \mathrm{mg}\end{array}$ & $\begin{array}{c}\text { Folate, } \\
\mu \mathrm{g}\end{array}$ & $\begin{array}{c}\text { Zinc, } \\
\text { mg }\end{array}$ \\
\hline Combined gap & -12.1 & -0.9 & -1641.5 & -647.8 & -23.8 & -1155.3 & 287.3 & 733.7 & -13.1 \\
\hline \multicolumn{10}{|c|}{ Social groups } \\
\hline General & 66.6 & 67.7 & -117.7 & -55.9 & -4.7 & -312.2 & 416.4 & 2240.8 & -0.4 \\
\hline OBC & 1.3 & 15.0 & -1134.2 & -634.8 & -21.2 & -991.8 & 336.4 & 748.8 & -11.3 \\
\hline SC & 23.8 & 7.5 & -313.3 & -585.0 & -19.8 & -971.9 & 325.5 & 730.2 & -7.9 \\
\hline ST & -22.0 & -6.3 & -1982.8 & -673.4 & -25.4 & -1230.9 & 270.2 & 699.6 & -14.5 \\
\hline Sig & * & $* *$ & * & & & & & * & * \\
\hline \multicolumn{10}{|c|}{ Family Size } \\
\hline 1 to 3 & 21.0 & 19.5 & -172.3 & 56.6 & -5.1 & -349.4 & 278.6 & 646.9 & -2.6 \\
\hline 4 to 6 & -19.5 & -3.6 & -1998.3 & -845.0 & -28.6 & -1390.7 & 294.2 & 767.8 & -15.7 \\
\hline$\geq 7$ & -75.5 & -52.1 & -4293.4 & -1750.2 & -56.7 & -2352.7 & 272.5 & 806.4 & -31.2 \\
\hline Sig & $* *$ & $* *$ & $* *$ & ** & ** & $* *$ & $* *$ & ** & ** \\
\hline \multicolumn{10}{|c|}{ Land holdings size } \\
\hline Landless & 17.6 & 23.5 & -656.2 & -255.6 & -11.3 & -611.7 & 268.4 & 726.1 & -5.6 \\
\hline Marginal & -14.8 & -2.3 & -1626.1 & -660.4 & -24.3 & -1153.0 & 288.3 & 642.5 & -13.2 \\
\hline Small & -21.5 & -5.2 & -1938.1 & -697.7 & -26.2 & -1347.1 & 289.5 & 715.3 & -14.8 \\
\hline Semi-medium & 5.9 & -9.9 & -1660.4 & -756.4 & -26.2 & -1177.6 & 317.7 & 1415.0 & -13.8 \\
\hline Medium & -24.9 & 1.9 & -2467.4 & -1145.8 & -33.2 & -1117.6 & 232.1 & 678.9 & -18.2 \\
\hline Sig & $* *$ & & * & * & * & & & ** & * \\
\hline
\end{tabular}

Significance $($ Sig $){ }^{\star} p<0.05 ;{ }^{*} p<0.01$.

was more in large land holding households and lesser in landless households. Sani \& Kemaw (2019) reported that the mean kilocalorie intake of food insecure households was $1440.37 \mathrm{kcal} / \mathrm{day}$, with the minimum and maximum being 597.65 kcal and $2048.13 \mathrm{kcal}$, respectively.

The regression (Table 4) shows that as the family size increases, the gap between the consumption of food groups increases except cereals and millets showing that larger family size are more food insecure than lesser family size. But the land size does not have any significant effect on the consumption and requirement of foods except for pulses, however the negative association shows that as the land size increases the gap between consumption and requirement decreases. The significant positive association between general social group and SC, ST and OBC in the gap between consumption and requirement of food groups showing that general group is in better side.

Rural India remains a caste-based society (Anderson, 2012) and castes differential in household food security status plays an important role in social wellbeing. Scheduled Tribe and Schedule Caste households were mostly food insecure household and General caste households were 2.3 time more likely to be 
Table 4. Regression of family size, social groups and land class on gap in household food consumption.

\begin{tabular}{|c|c|c|c|c|c|c|c|c|c|}
\hline Category & $\begin{array}{l}\text { Cereals } \\
\& \text { millets }\end{array}$ & $\begin{array}{l}\text { Pulses \& } \\
\text { legumes }\end{array}$ & $\begin{array}{l}\text { Leafy } \\
\text { veg }\end{array}$ & $\begin{array}{l}\text { Other } \\
\text { veg }\end{array}$ & $\begin{array}{c}\text { Roots \& } \\
\text { tubers }\end{array}$ & Fruits & $\begin{array}{c}\text { Milk \& } \\
\text { milk pdts }\end{array}$ & Sugar & $\begin{array}{c}\text { Fats \& } \\
\quad \text { oil }\end{array}$ \\
\hline Family Size & 25.9 & $57.1^{\star *}$ & $68.0^{\star *}$ & $137.3^{* *}$ & $58.2^{\star *}$ & $76.5^{* *}$ & $272.3^{* *}$ & $14.2^{* *}$ & $17.4^{\star *}$ \\
\hline $\begin{array}{c}\text { Landholding } \\
\text { size, ha }\end{array}$ & -29.6 & $-13.6^{*}$ & -15.1 & -15.1 & -5.9 & 10.4 & -4.0 & -6.6 & -0.9 \\
\hline \multicolumn{10}{|c|}{ Social groups (General category as reference) } \\
\hline SC & -318.5 & $150.1^{\star *}$ & -11.3 & 248.1 & $279^{* *}$ & $210.4^{\star *}$ & $-215.0^{\star \star}$ & -7.80 & 35.2 \\
\hline ST & 91.8 & $163.5^{\star *}$ & 12.7 & $332.0^{*}$ & $286^{* *}$ & $295.7^{\star *}$ & $256.6^{\star *}$ & 11.20 & $40.9^{*}$ \\
\hline $\mathrm{OBC}$ & -70.8 & $154.7^{\star *}$ & -32.2 & 248.8 & $213.3^{*}$ & $263.0^{* *}$ & $227.3^{\star *}$ & 2.60 & 25.1 \\
\hline $\mathrm{R}$ square & 0.05 & 0.47 & 0.25 & 0.31 & 0.21 & 0.46 & 0.90 & 0.12 & 0.34 \\
\hline
\end{tabular}

${ }^{\star} p<0.05 ;{ }^{* *} p<0.01$.

food secure than the Schedule Caste household (Sarkar \& Shekhar, 2017). The results of the present study also showed that the SC and ST households consumed lesser foods than that is expected to be consumed when compared to the general caste. The gap between the requirement and consumed nutrients like protein, calorie, iron, vitamin A and zinc was also significantly high in ST group.

In general, food insecure households were characterized by smaller household size. Large family size has significant relationship with much greater risk of poverty. This was similar to the results of the present study and showed that the consumption was more than the requirement of cereals and vegetables in households having lesser members.

Average size of land was much higher in the food secure household (2.4 acres) compared to food insecure ( 0.9 acre), and food insecure with hunger households (0.1 acre) (Sarkar \& Shekhar, 2017). Frelat et al. (2016) showed that farm size is a determinant of food security in sub-Saharan Africa and as farm size increases, the probability of a household being food-secure also increases. The results of the present study were in contrast to the above studies. The gap between consumption of foods irrespective of land holding size was more except cereals and millets and the gap was more in the large landholding households. The linear regression also confirmed the results.

The limitation of this study was that the food and nutrient consumption was collected at one time of a year and as the food consumption may vary based on seasons, further study can be done with the data collected at different time of a year to understand the food and nutrient gap in different seasons. Further research can be also done using data collected using 24 hour diet recall data to access the nutrient gap among different age groups and gender.

\section{Conclusion}

The study demonstrates social groups, family size and landholding size are important factors for rural household food security. Improving the knowledge on 
consumption of own production and marketing of excess produce should be emphasized. Research studies, government policies and entitlements should focus on decreasing the gap between the consumption and household requirement by increasing the accessibility to foods and make the rural households food secured.

\section{Acknowledgements}

The authors are thankful to the community members of Koraput district, Odisha for their active support and their valuable time spent with us during the survey. The team also acknowledges the untiring work of following field investigators for the data collection from the study areas and data entry: Mr. Purna Chandra Samantray, Mr. Sita Prasad Senapati, Mr. Malay Kumar Nayak, Mr. Navjot Singh, Mr. Ghasi Takri, Mr. Haribandhu Harijan, Mr. Antarjyami Bisoi and Ms. Sweta Sheloni Khura.

\section{Conflicts of Interest}

The authors declare no conflicts of interest regarding the publication of this paper.

\section{References}

Abdullah, Z. D., Shah, T., Ali, S., Ahmad, W., Din, I. U., \& Ilyas, A. (2019). Factors Affecting Household Food Security in Rural Northern Hinterland of Pakistan. Journal of the Saudi Society of Agricultural Sciences, 18, 201-210. https://doi.org/10.1016/j.jssas.2017.05.003

Agidew, A. A., \& Singh, K. N. (2018). Determinants of Food Insecurity in the Rural Farm Households in South Wollo Zone of Ethiopia: The Case of the Teleyayen Sub-Watershed. Agricultural and Food Economics, 6, Article No. 10. https://doi.org/10.1186/s40100-018-0106-4

Ahmed, U. L., Ying, L., Bashir, M. K., Abid, M., \& Zulfiqar, F. (2017). Status and Determinants of Small Farming Households' Food Security and Role of Market Access in Enhancing Food Security in Rural Pakistan. PLOS ONE, 12, e0185466.

https://doi.org/10.1371/journal.pone.0185466

Ali, M. M., Rehman, H., \& Husain, S. M. (2012). Status of Food Insecurity at Household Level in Rural India: A Case Study of Uttar Pradesh. International Journal of Physical and Social Sciences, 2, 227-244.

Anderson, S. (2012). Caste Dominance in Rural India: Cause and Effect. Ideas for India. http://www.ideasforindia.in/topics/governance/caste-dominance-in-rural-india-causeand-effect.html

Behrman, J. R., \& Deolalikar, A. B. (1990). The Intrahousehold Demand for Nutrients in Rural South India: Individual Estimates, Fixed Effects, and Permanent Income. The Journal of Human Resources, 25, 665-696. https://doi.org/10.2307/145671

De Cock, N., D’Haese, M., Vink, N., van Rooyen, C. J., Staelens, L., Schönfeldt, H. C., \& D'Haese, L. (2013). Food Security in Rural Areas of Limpopo Province, South Africa. Food Security, 5, 269-282. https://doi.org/10.1007/s12571-013-0247-y

FAO (Food and Agricultural Organization of the United Nations) (2003). Chapter 2. Food Security: Concepts and Measurement. In Trade Reforms and Food Security, 
Conceptualizing the Linkages. Food and Agricultural Organization of the United Nations. http://www.fao.org/3/y4671e/y4671e06.htm

FAO (Food and Agricultural Organization of the United Nations) (2008). Deriving Food Security Information from National Household Budget Surveys: Experiences, Achievements, Challenges. Food and Agricultural Organization of the United Nations, Rome.

Frelat, R., Lopez-Ridaura, S., Giller, K. E., Herrero, M., Douxchamps, S., Djurfeldt, A. A., Erenstein, O., Henderson, B., Kassie, M., Paul, B. K., Rigolot, C., Ritzema, R. S., Rodriguez, D., van Asten, P. J. A., \& van Wijk, M. T. (2016). Drivers of Household Food Availability in Sub-Saharan Africa Based on Big Data from Small Farms. Proceedings of the National Academy of Sciences of the United States of America, 113, 458-463. https://doi.org/10.1073/pnas.1518384112

ICMR (2017). Indian Food Composition Tables. National Institute of Nutrition. Hyderabad, India.

Joshi, G. R., \& Joshi, N. B. (2016). Determinants of Household Food Security in the Eastern Region of Nepal. SAARC Journal of Agriculture, 14, 174-188. https://doi.org/10.3329/sja.v14i2.31257

Muraoka, R., Jin, S., \& Jayne, T. S. (2018). Land Access, Land Rental and Food Security: Evidence from Kenya. Land Use Policy, 70, 611-622.

https://doi.org/10.1016/j.landusepol.2017.10.045

National Institute of Nutrition (2011). Dietary Guidelines for Indians-A Manual. Indian Council of Medical Research, National Institute of Nutrition.

Nkomoki, W., Bavorova, M., \& Banout, J. (2019). Factors Associated with Household Food Security in Zambia. Sustainability, 11, Article No. 2715. https://doi.org/10.3390/su11092715

Olayemi, A. O. (2012). Effects of Family Size on Household Food Security in Osun State, Nigeria. Asian Journal of Agriculture and Rural Development, 2, 136-141.

Rammohan, A., \& Pritchard, B. (2014). The Role of Landholding as a Determinant of Food and Nutrition Insecurity in Rural Myanmar. World Development, 64, 597-608. https://doi.org/10.1016/j.worlddev.2014.06.029

Sani, S., \& Kemaw, B. (2019). Analysis of Households Food Insecurity and Its Coping Mechanisms in Western Ethiopia. Agricultural and Food Economics, 7, Article No. 5. https://doi.org/10.1186/s40100-019-0124-x

Sarkar, S., \& Shekhar, C. (2017). Household Food Insecurity and Coping Strategies in a Rural Community of West Bengal. Social Science Spectrum, 3, 16-26.

Sekhampu, T. J. (2013). Determinants of the Food Security Status of Households Receiving Government Grants in Kwakwatsi, South Africa. Mediterranean Journal of Social Sciences, 4, 147-153.

Shone, M., Demissie, T., Yohannes, B., \& Yohannis, M. (2017). Household Food Insecurity and Associated Factors in West Abaya District, Southern Ethiopia, 2015. Agriculture \& Food Security, 6, Article No. 2. https://doi.org/10.1186/s40066-016-0080-6 